\title{
Antiproliferation of Cryptocarya concinna- derived cryptocaryone against oral cancer cells involving apoptosis, oxidative stress, and DNA damage
}

Hsun-Shuo Chang ${ }^{1,2+}$, Jen-Yang Tang ${ }^{3,4,5+}$, Ching-Yu Yen ${ }^{6,7}$, Hurng-Wern Huang ${ }^{8}$, Chang-Yi Wu ${ }^{9}$, Yi-An Chung ${ }^{10}$, Hui-Ru Wang ${ }^{10}$, Ih-Sheng Chen ${ }^{1,2}$, Ming-Yii Huang ${ }^{3,4^{*}}$ and Hsueh-Wei Chang ${ }^{10,11,12,13^{*}}$ (i)

\begin{abstract}
Background: Cryptocarya-derived crude extracts and their compounds have been reported to have an antiproliferation effect on several types of cancers but their impact on oral cancer is less well understood.

Methods: We examined the cell proliferation effect and mechanism of C. concinna-derived cryptocaryone (CPC) on oral cancer cells in terms of cell viability, apoptosis, reactive oxygen species (ROS), mitochondrial depolarization, and DNA damage.

Results: We found that CPC dose-responsively reduced cell viability of two types of oral cancer cells (Ca9-22 and CAL 27) in MTS assay. The CPC-induced dose-responsive apoptosis effects on Ca9-22 cells were confirmed by flow cytometrybased sub-G1 accumulation, annexin V staining, and pancaspase analyses. For oral cancer Ca9-22 cells, CPC also induced oxidative stress responses in terms of ROS generation and mitochondrial depolarization. Moreover, $\mathrm{YH} 2 \mathrm{AX}$ flow cytometry showed DNA damage in CPC-treated Ca9-22 cells. CPC-induced cell responses in terms of cell viability, apoptosis, oxidative stress, and DNA damage were rescued by $\mathrm{N}$-acetylcysteine pretreatment, suggesting that oxidative stress plays an important role in CPC-induced death of oral cancer cells.
\end{abstract}

Conclusions: CPC is a potential ROS-mediated natural product for anti-oral cancer therapy.

Keywords: Cryptocarya concinna, Cryptocaryone, Oral cancer, Apoptosis, Oxidative stress, YH2AX

\section{Background}

Oral cancer is the sixth most common cancer in the world $[1,2]$. Oral cancer is easy to detect clinically but is frequently ignored by patients resulting in high mortality rates [3]. Although several oral tumor markers have been reported $[4,5]$, these efforts focused on detection rather than therapy and effective anti-oral cancer therapies are still needed.

Cryptocarya (family Lauraceae) is widely found in the tropics and subtropics [6]. Its crude extracts have been

\footnotetext{
* Correspondence: miyihu@gmail.com; changhw@kmu.edu.tw

${ }^{\dagger}$ Equal contributors

${ }^{3}$ Department of Radiation Oncology, Faculty of Medicine, College of

Medicine, Kaohsiung Medical University, Kaohsiung, Taiwan

${ }^{10}$ Department of Biomedical Science and Environmental Biology, Kaohsiung

Medical University, Kaohsiung, Taiwan

Full list of author information is available at the end of the article
}

demonstrated to have an antiproliferative ability against cancer. For example, methanolic extracts of the leaves of C. griffithiana and the roots of C. concinna can inhibit cell proliferation of human HL60 promyelocytic leukemia cells [7] and oral cancer cells [8], respectively. The ethanolic extracts of the fruit and trunk bark of $C$. obovata have been reported to have an antiproliferative effect against human KB cells [9].

Several Cryptocarya-derived compounds have been found to have diverse biological functions, i.e., antidengue virus by alkylated flavanones [10], anti-HIV by phenanthroindolizidine alkaloids [11], anti-tuberculosis by pinocembrin [12], anti-plasmodial by (+)-N-methylisococlaurine, atherosperminine, and 2-hydroxy-atherosperminine [13], anti-trypanosomal by $7^{\prime}, 8^{\prime}$-dihydroobolactone [14], and 
anti-inflammatory by (2S)-5,7-dihydroxyflavanone and cryptocaryanone B [15].

Recently, Cryptocarya-derived compounds have been reported to have an antiproliferation effect on cancer. For example, the proliferation of leukemia cells was inhbitied by $C$. costata-derived $2^{\prime}, 4^{\prime}$-dihydroxy-5',6'dimethoxychalcone and isodidymocarpin [16] and $C$. konishii-derived by desmethylinfectocaryone, infectocaryone, and cryptocaryone (CPC) [17]. Among these Cryptocarya-derived compounds, we are interested in the anticancer effect of $\mathrm{CPC}$, which is one of the major constituents in the commonly distributed evergreen plant C. concinna in Taiwan [18].

Although the anticancer effect of CPC, a kind of dihydrochalcone, had been reported in some cancer types such as murine leukemia [17] and prostate cancer [19], few studies have addressed its antiproliferative effect on oral cancer. Moreover, the cell killing mechanism of cryptocaryone in cancer remains unclear. Recently, reactive oxygen species (ROS) generation was reported to be involved in Corema album-derived dihydrochalcone induced cytotoxicity for colon cancer cells [20]. Accordingly, the relationship between ROS generation and CPC effect for oral cancer cells is worth examining.

This study evaluates possible anticancer functions of CPC and explores its drug mechanisms in terms of cell viability, cell cycle analysis, apoptosis, ROS generation, mitochondrial depolarization, and DNA damage detection. The role of oxidative stress in CPC's effect on oral cancer cells is also addressed.

\section{Methods}

\section{Plant material and isolation}

C. concinna was identified by one of the authors (Ih-Sheng Chen) and its roots were collected at Mudan, Pingtung County, Taiwan, in May 2004. A voucher specimen (Chen6153) has been deposited in the Herbarium of the School of Pharmacy, College of Pharmacy, Kaohsiung Medical University. The dried roots $(7.7 \mathrm{Kg})$ of C. concinna were processed by slicing and cold methanolextraction three times at room temperature. Finally, the solution was evaporated under reduced pressure to yield the methanolic extract (800 g; yield: methanolic extract/ dried roots $=10.4 \%)$ [8]. CPC (5.7 g; yield: $\mathrm{CPC} /$ methanolic extract $=0.7 \%$ ) was isolated from the root of C. concinna as described previously [19]. In brief, the methanolic extract was partitioned between chloroform/water (1:1) to yield a chloroform fraction and a water fraction. The chloroform fraction was subjected to silica gel column chromatography and eluted with a gradient of chloroform-methanol to produce 13 fractions (A-1-A-13). CPC was then obtained from fraction A-3 (chloroform-methanol 100:1) and the structure of CPC was determined by spectral analyses (Additional file 1).

\section{Cell cultures and chemicals}

Two human oral cancer cell lines (Ca9-22 [21] and CAL 27 [22]), purchased from the Cell Bank, RIKEN BioResource Center (Tsukuba, Japan) and the American Type Culture Collection (ATCC; Virginia, USA), respectively, were incubated in DMEM/F12 (3:2) medium (Gibco, Grand Island, NY, USA) supplemented with $10 \%$ fetal bovine serum (Gibco), $100 \mathrm{U} / \mathrm{ml}$ penicillin, $100 \mu \mathrm{g} / \mathrm{ml}$ streptomycin, and $0.03 \%$ glutamine. Normal gingival fibroblast (HGF-1) was purchased from ATCC and maintained in DMEM medium (Gibco, Grand Island, NY, USA) with a similar supplement with $1 \mathrm{mM}$ pyruvate as described above. Cells were incubated in humidified air at $37{ }^{\circ} \mathrm{C}$ with $5 \% \mathrm{CO}_{2}$. $\mathrm{N}$-acetylcystein (NAC) was purchased from Sigma (St. Louis, MO, USA) for pretreatment before CPC application. Passage numbers of the oral cancer (Ca9-22 and CAL 27) cells used in this study were $15-22$ and $8-15$, respectively.

\section{Cell viability}

Cell viability was determined using the CellTiter $96^{\circ}$ AQueous One Solution Cell Proliferation Assay (MTS) (Promega Corporation, Madison,WI, USA) as previously described [21]. Two oral cancer cell lines (Ca9-22 and CAL 27) were seeded at $1 \times 10^{5}$ cells per well and HGF1 cells were seeded at $4 \times 10^{4}$ cells per well in a 6-well plate, respectively. After seeding for $24 \mathrm{~h}$, cells were treated with CPC at indicated concentrations for $24 \mathrm{~h}$ and cell viability was determined by an ELISA reader at $490 \mathrm{~nm}$.

\section{Determination of cell cycle distribution}

Propidium iodide (PI) (Sigma, St Louis, MO, USA) was added to stain the cellular DNA content [23]. In brief, $3 \times 10^{5}$ cells per well in 6 well plates were seeded overnight and then treated with the vehicle (0.05\% DMSO) or 3, 6, 9, $12 \mu \mathrm{M}$ of CPC for $24 \mathrm{~h}$. After cells were harvested and washed twice with PBS, they were fixed overnight with $70 \%$ ethanol. Subsequently, the cell pellets were resuspended in $50 \mu \mathrm{g} / \mathrm{ml}$ PI for $30 \mathrm{~min}$ at $37{ }^{\circ} \mathrm{C}$ in darkness. The cell cycle distribution was evaluated by a flow cytometer (BD Accuri ${ }^{\text {tix }}$ C6; BectonDickinson, Mansfield, MA, USA) and BD Accuri ${ }^{\mathrm{mi}}$ C6 software (version 1.0.264).

\section{Determination of apoptosis by annexin V/PI}

Apoptosis was detected by annexin V (Strong Biotect Corporation, Taipei, Taiwan)/PI (Sigma, St Louis, MO, USA) as described in [24]. Briefly, $3 \times 10^{5}$ cells per well in 6 well plates were seeded for $24 \mathrm{~h}$ and then treated with the vehicle or indicated concentrations of CPC for $24 \mathrm{~h}$. Cells were then incubated with $100 \mu \mathrm{l}$ binding buffer containing $2 \mu \mathrm{l}$ of annexin-V-fluorescein isothiocyanate (FITC) stock $(0.25 \mu \mathrm{g} / \mu \mathrm{l})$ and $2 \mu \mathrm{l}$ of PI stock 
$(1 \mathrm{mg} / \mathrm{ml})$ for $30 \mathrm{~min}$. Finally, it was suspended with $400 \mu \mathrm{l}$ PBS for flow cytometry analysis (BD Accuri ${ }^{\text {tix }}$ C6; Becton-Dickinson).

\section{Determination of apoptosis by pancaspase activity}

The apoptosis was also detected by the measurement of caspase activation [25]. In this study, the generic activation of pancaspases (Caspase-1, 3, 4, 5, 6, 7, 8, 9) was determined by the generic caspase activity assay kit (Abcam, Cambridge, UK) as described in [26]. Briefly, Ca9-22 cells were seeded as $3 \times 10^{5}$ cells per well in 6 well plates with $2 \mathrm{ml}$ medium. The next day, Ca9-22 cells were treated with CPC for $24 \mathrm{~h}, 2 \mu \mathrm{l}$ of 500X TF2-VAD-FMK was then added, and the cells were incubated at $37{ }^{\circ} \mathrm{C}, 5 \% \mathrm{CO}_{2}$ for $2 \mathrm{~h}$. Cells were washed with PBS twice and resuspended in $0.5 \mathrm{ml}$ of assay buffer for immediate flow cytometry measurement (BD Accuri ${ }^{\text {ind }}$ C6; Becton-Dickinson).

\section{Determination of intracellular ROS}

The dye $2^{\prime}, 7^{\prime}$-dichlorodihydrofluorescein diacetate (DCFHDA) was used to detect ROS by its fluorescence change [27]. Cells at the density of $3 \times 10^{5}$ in $2 \mathrm{ml}$ medium per well in 6 well plates were seeded for $24 \mathrm{~h}$. Different concentrations of CPC were added to Ca9-22 cells for $3 \mathrm{~h}$. After washing with PBS, $100 \mathrm{nM}$ DCFH-DA in PBS were added to the cells in 6 well plates in a cell culture incubator for $30 \mathrm{~min}$. After trypsinization, PBS washing, and centrifugation, cell pellets were resuspended in $1 \mathrm{ml}$ PBS before flow cytometry analysis (BD Accuri ${ }^{\mathrm{in}}$ C6; Becton-Dickinson) and its software.

\section{Determination of mitochondrial membrane potential (MitoMP)}

MitoProbe ${ }^{\mathrm{mu}} \mathrm{DiOC}_{2}(3)$ assay kit (Invitrogen, Eugene, OR, USA) was applied to analyze MitoMP as described previously [28, 29]. Briefly, $3 \times 10^{5}$ cells in $2 \mathrm{ml}$ medium per well in 6 well plates were seeded for $24 \mathrm{~h}$. After CPC treatment, $10 \mu \mathrm{l}$ of $10 \mu \mathrm{M} \mathrm{DiOC}{ }_{2}(3)$ was added per well and incubated in a cell culture incubator for $30 \mathrm{~min}$. After harvesting, cells were resuspended in $1 \mathrm{ml}$ PBS for flow cytometry analysis (BD Accuri ${ }^{\text {Th }}$ C6; Becton-Dickinson).

\section{Determination of DNA damage by $\mathrm{YH} 2 \mathrm{AX} / \mathrm{PI}$}

DNA double strand breaks were detected by flow cytometry as described previously [30]. In brief, CPC-treated cells were fixed in $70 \%$ ethanol, washed with BSA-T-PBS solution ( $1 \%$ bovine serum albumin and $0.2 \%$ Triton X-100 in PBS; Sigma), and incubated at $4{ }^{\circ} \mathrm{C}$ for $1 \mathrm{~h}$ in $100 \mu \mathrm{l}$ of BSA-T-PBS solution containing $0.2 \mu \mathrm{g}$ p-Histone H2A.X (Ser 139) monoclonal antibody (Santa Cruz Biotechnology, Santa Cruz, CA, USA). Cells were washed and suspended for $1 \mathrm{~h}$ in a 1:50 dilution of Alexa Fluor 488-tagged secondary antibody (Jackson Laboratory, Bar Harbor, ME, USA) for staining for $30 \mathrm{~min}$ at room temperature. Finally, the cells were resuspended in $20 \mu \mathrm{g} / \mathrm{ml}$ of PI for flow cytometry analysis (BD Accuri ${ }^{\mathrm{Tw}}$ C6; Becton-Dickinson).

\section{Statistical analysis}

Group differences of the same drug treatment with different concentrations were analyzed by one-way ANOVA with Tukey HSD Post Hoc Test using JMP ${ }^{\circ} 10$ software [21]. No overlapping by the same lower-case letter indicated significant differences.

\section{Results}

\section{Assessment of antiproliferation of CPC and the effect of NAC pretreatment}

In the MTS assay (Fig. 1), the cell viability (\%) of two oral cancer cells (Ca9-22 and CAL 27) at indicated concentrations of $\mathrm{CPC}$ were dose-responsively decreased $(P<0.05-0.001$ compared to the vehicle). In contrast, the cell viabilities of oral normal HGF-1 cells were similar to the control at 3 and $6 \mu \mathrm{M}$ of $\mathrm{CPC}$ although cell viability decreased at 9 and $12 \mu \mathrm{M}$. The $\mathrm{IC}_{50}$ values of CPC for oral cancer Ca9-22 and CAL 27 cells were 9.87 and $3.45 \mu \mathrm{M}$, respectively, whereas $\mathrm{IC}_{50}$ was undetected in the CPC-treated oral normal HGF-1 cells under the same CPC treatment.

NAC, an ROS scavenger, is commonly used to validate the role of oxidative stress in drug-induced ROSmediated effects [31-34]. NAC pretreatment was performed to examine the possible role of oxidative stress in $\mathrm{CPC}$-induced cell death, showing that the CPC-

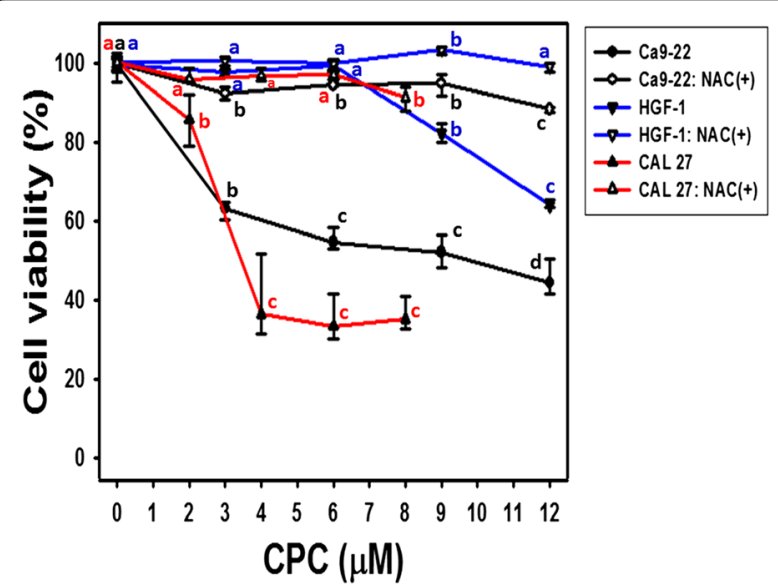

Fig. 1 Cell viabilities of CPC-treated oral cancer cells and the effect of NAC pretreatment. Oral cancer (Ca9-22 and CAL 27) cells and oral normal (HGF-1) cells were chosen. With or without 2 mM NAC pretreatment for 1 h, Ca9-22 and HGF-1 cells were treated with 3, 6, 9, and $12 \mu \mathrm{M}$ of CPC and CAL 27 cells were treated with 2, 4, 6, and $8 \mu \mathrm{M}$ of CPC for $24 \mathrm{~h}$ incubation. The cell viability was measured by the MTS assay. Data, means \pm SDs $(n=6)$. For the same drug treatment of different concentrations, data marks (a to d) without overlapping by the same lower-case letter significantly differed (one-way ANOVA with Tukey HSD Post Hoc Test) 
induced antiproliferation in oral cancer cells and normal cells were almost completely rescued compared to controls (Fig. 1).

\section{Assessment of sub-G1 accumulation of CPC and the effect of NAC pretreatment}

The distribution profiles of $\mathrm{CPC}$-induced cell cycle changes of oral cancer Ca9-22 cells are shown in Fig. 2a (top). After CPC treatment (Fig. 2b), the subG1 populations of CPC $(0-12 \mu \mathrm{M})$-treated Ca9-22 cells were dose-responsively increased $(P<0.001)$. In contrast, the G0/G1 and G2/M populations of CPCtreated Ca9-22 cells were almost dose-responsively decreased $(P<0.001)$.

The distribution profiles of NAC pretreatment effect against $\mathrm{CPC}$-induced cell cycle changes are shown in Fig. 2a (bottom). After NAC pretreatment, i.e., NAC + CPC (Fig. 2b, right), the CPC-induced cell cycle changes as mentioned above recovered to normal distributions compared to CPC only (Fig. 2b, left) and untreated controls.

\section{Assessment of annexin V/PI-based apoptosis of CPC and the effect of NAC pretreatment}

To further validate the role of apoptosis, the annexin V/PI profiles of CPC-treated oral cancer Ca9-22 cells were demonstrated by flow cytometry (Fig. 3a, top). In Fig. 3b, the populations of annexin $\mathrm{V}$-positive intensities for CPC $(0-12 \mu \mathrm{M})$-treated Ca9-22 cells were dose-responsively increased $(P<0.05-0.001)$.

The annexin V/PI profiles of NAC pretreatment effect against $\mathrm{CPC}$-induced apoptosis were also demonstrated in Fig. 3a (bottom). After NAC pretreatment, i.e., NAC $+\mathrm{CPC}$ (Fig. 3b), the CPC-induced apoptosis changes as mentioned above recovered to normal levels compared to CPC only and untreated controls.

\section{Assessment of pancaspase-based apoptosis of CPC and the effect of NAC pretreatment}

To further validate the role of apoptosis, the pancaspase profiles of CPC-treated oral cancer Ca9-22 cells were demonstrated by flow cytometry (Fig. 4a, top). In Fig. 4b, the populations of pancaspase-positive intensities for CPC (0-12 $\mu \mathrm{M})$-treated Ca9-22 cells were dose-responsively increased $(P<0.001)$.

The pancaspase profiles of NAC pretreatment effect against CPC-induced apoptosis were also demonstrated in Fig. 4a (bottom). After NAC pretreatment, i.e., NAC+ CPC (Fig. 4b), the CPC-induced apoptosis changes as mentioned above recovered to normal levels compared to CPC only and untreated controls.

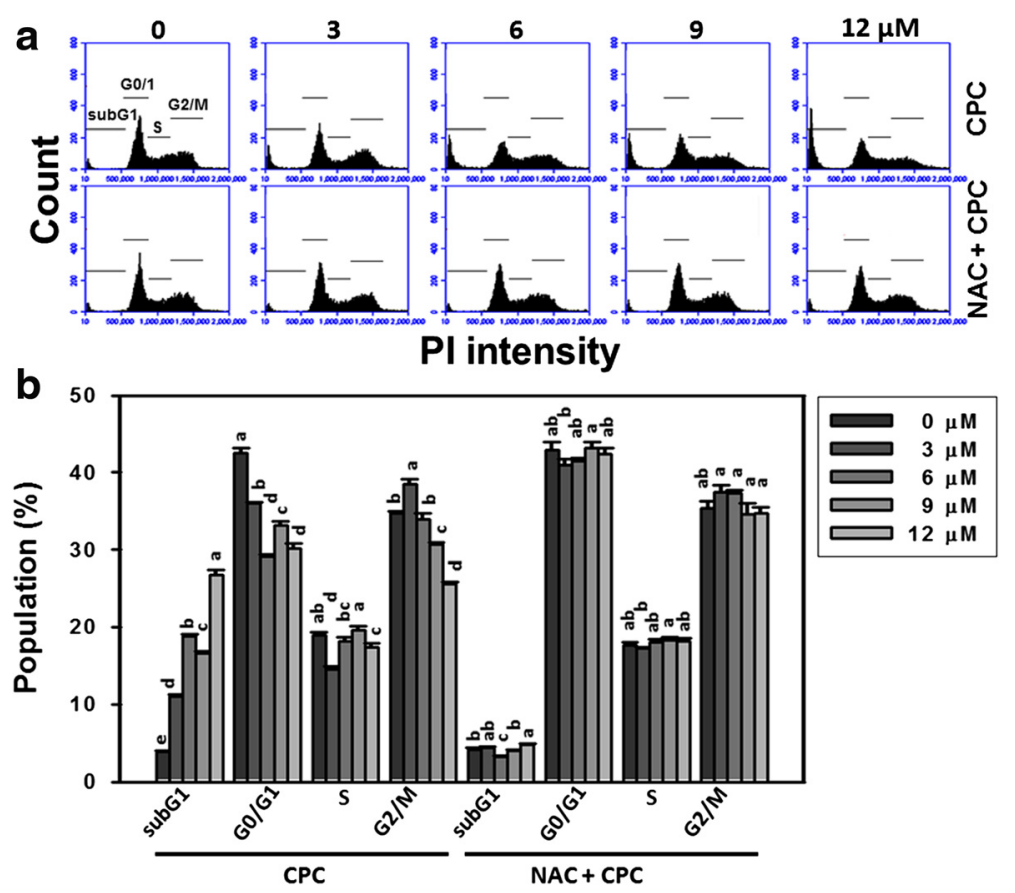

Fig. 2 The sub-G1 accumulations of CPC-treated oral cancer Ca9-22 cells and the effect of NAC pretreatment. With or without 2 mM NAC pretreatment for $1 \mathrm{~h}$, Ca9-22 cells were treated with $0,3,6,9$, and $12 \mu \mathrm{M}$ of CPC for $24 \mathrm{~h}$. a Representative flow cytometry-based cell cycle distribution profiles of CPC-treated Ca9-22 cells. The cell cycle phases are underlined in each panel. b Quantification analysis for the subG1 percentages in Fig. 2a. Data, mean \pm SD $(n=3)$. For the same drug treatment of different concentrations, data marks (a to d) without overlapping by the same lower-case letter significantly differed (one-way ANOVA with Tukey HSD Post Hoc Test) 

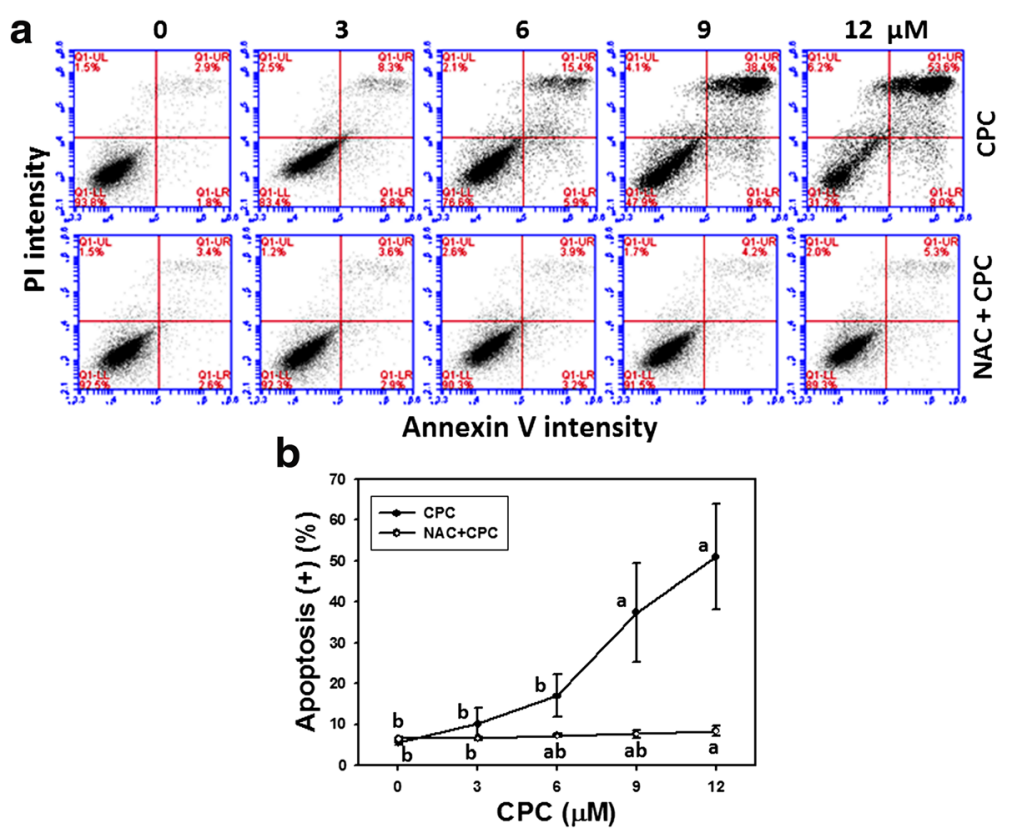

Fig. 3 Annexin V/PI-based apoptosis of CPC-treated oral cancer Ca9-22 cells and the effect of NAC pretreatment. With or without 2 mM NAC pretreatment for $1 \mathrm{~h}$, Ca9-22 cells were treated with $0,3,6,9$, and $12 \mu \mathrm{M}$ of CPC for $24 \mathrm{~h}$. a Representative results of flow cytometry-based annexin V/PI double staining of CPC-treated Ca9-22 cells. Annexin V (+)/PI (+) and Annexin V (+)/PI (-) were calculated as the apoptosis (+) in each panel. $\mathbf{b}$ Quantification analysis of apoptosis for CPC-treated Ca9-22 cells in Fig. 3a. Data, mean \pm SD $(n=3)$. For the same drug treatment of different concentrations, data marks ( $a$ and $b$ ) without overlapping by the same lower-case letter significantly differed (one-way ANOVA with Tukey HSD Post Hoc Test)

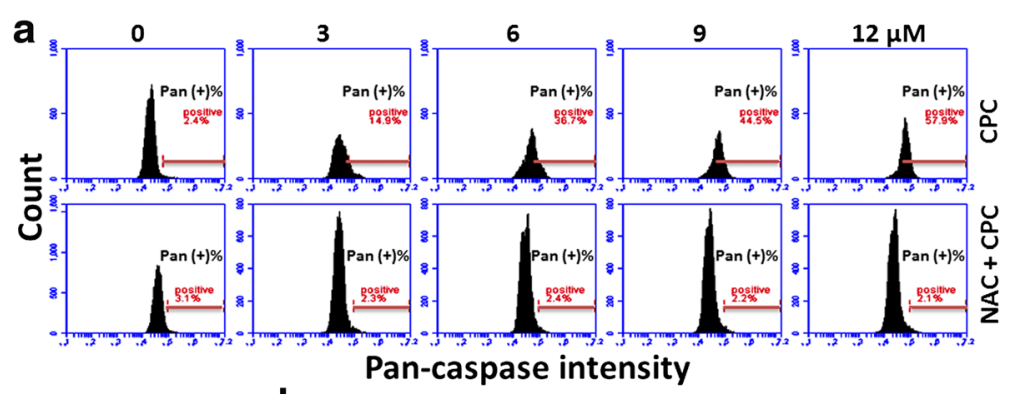

b

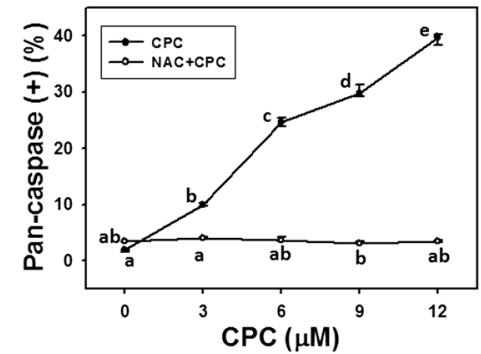

Fig. 4 Generic caspase-based apoptosis of CPC-treated oral cancer Ca9-22 cells and the effect of NAC pretreatment. a With or without 2 mM NAC pretreatment for $1 \mathrm{~h}$, Ca9-22 cells treated with $0,3,6$, 9, and $12 \mu \mathrm{M}$ of CPC for $24 \mathrm{~h}$ were stained with $1 \mu \mathrm{ll}$ 500X TF2-VAD-FMK. The right side indicates the pancaspase (Pan) positive region in each panel. $\mathbf{b}$ Quantificative analysis of pan-caspase fluorescent intensity. Data, mean \pm SD $(n=3)$. For the same drug treatment of different concentrations, data marks (a to e) without overlapping by the same lower-case letter significantly differed (one-way ANOVA with Tukey HSD Post Hoc Test) 


\section{Assessment of ROS generation of CPC and the effect of NAC pretreatment}

Accumulated evidence showed that ROS-generating drugs and natural products may lead to apoptosis [35-38]. To validate the role of $\mathrm{ROS}$ in the CPC induced cell death effect, an ROS staining dye (DCFH-DA) was applied to flow cytometry. Figure 5 a shows the ROS staining profiles of CPC-treated $\mathrm{Ca} 9-22$ cells at $3 \mathrm{~h}$ incubation. After $\mathrm{CPC}$ treatment, the relative ROS-positive staining of CPC (0-12 $\mu \mathrm{M})$-treated Ca9-22 cells were doseresponsively induced $(P<0.001)$ (Fig. $5 b)$.

The ROS staining profiles of NAC pretreatment effects against CPC-induced ROS generation were also demonstrated in Fig. 5a (bottom). After NAC pretreatment, i.e., $\mathrm{NAC}+\mathrm{CPC}$ (Fig. 5b), the CPC-induced ROS changes as mentioned above recovered to normal levels compared to $\mathrm{CPC}$ only and untreated controls.

\section{Assessment of MitoMP of CPC and the effect of NAC pretreatment}

To validate the role of MitoMP in the CPC-induced effects, a mitochondrial membrane potential-sensitive staining dye $\left(\mathrm{DiOC}_{2}(3)\right)$ was applied to flow cytometry. Figure 6a shows the MitoMP staining profiles of CPCtreated Ca9-22 cells at $24 \mathrm{~h}$ incubation. After CPC treatment, the relative MitoMP-positive staining of
CPC (0-12 $\mu \mathrm{M})$-treated Ca9-22 cells were doseresponsively decreased $(P<0.001)$ (Fig. 6b).

The MitoMP staining profiles of NAC pretreatment effects against $\mathrm{CPC}$-induced ROS generation were also demonstrated in Fig. 6a (bottom). After NAC pretreatment, i.e., $\mathrm{NAC}+\mathrm{CPC}$ (Fig. 6b), the CPC-induced MitoMP changes as mentioned above recovered to near normal levels compared to $\mathrm{CPC}$ only and untreated controls.

\section{Assessment of $\mathrm{\gamma H} 2 \mathrm{AX} / \mathrm{PI}$-based DNA damage of CPC and the effect of NAC pretreatment}

To further examine the role of DNA damage in CPCinduced effects, the DNA double strand break (DSB) marker $(\gamma \mathrm{H} 2 \mathrm{AX})$ was chosen for use in flow cytometry. Figure $7 \mathrm{a}$ displays the $\gamma \mathrm{H} 2 \mathrm{AX} / \mathrm{PI}$ staining profiles of CPC-treated $\mathrm{Ca} 9-22$ cells at $24 \mathrm{~h}$ incubation. After $\mathrm{CPC}$ treatment, the $\gamma \mathrm{H} 2 \mathrm{AX}$-positive staining of CPC (0-12 $\mu \mathrm{M})$-treated Ca9-22 cells were dose-responsively decreased $(P<0.001)$ (Fig. $7 \mathrm{~b})$.

The $\gamma \mathrm{H} 2 \mathrm{AX}$ staining profiles of NAC pretreatment effect against $\mathrm{CPC}$-induced DNA damage were also demonstrated in Fig. 7a (bottom). After NAC pretreatment, i.e., $\mathrm{NAC}+\mathrm{CPC}$ (Fig. 7b), the CPC-induced $\gamma \mathrm{H} 2 \mathrm{AX}$ changes as mentioned above recovered to near normal levels compared to CPC only and untreated controls.

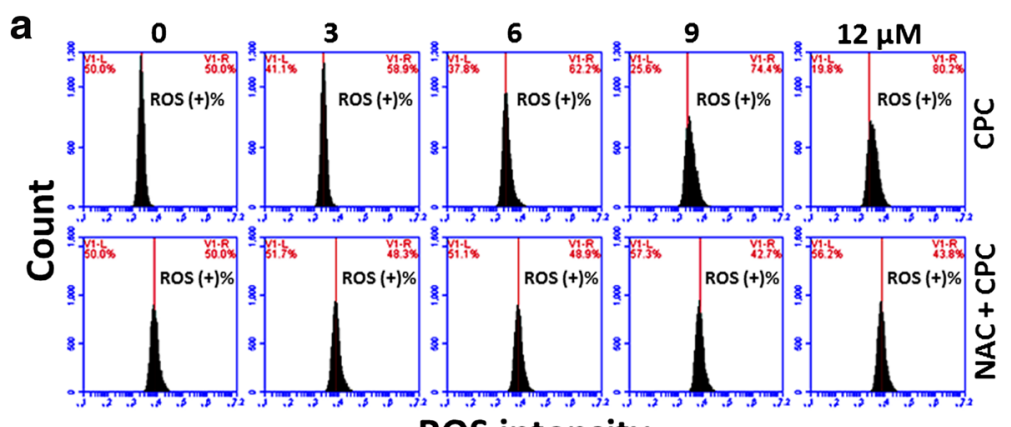

b

ROS intensity

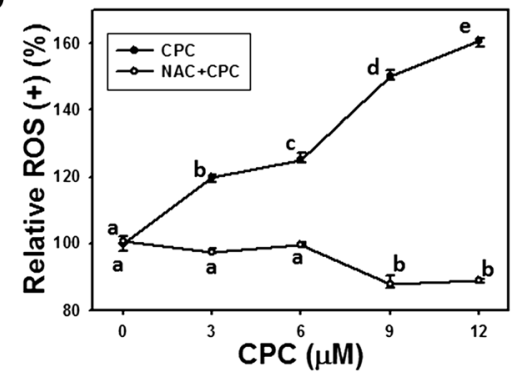

Fig. 5 ROS generation of CPC-treated oral cancer Ca9-22 cells and the effect of NAC pretreatment. With or without 2 mM NAC pretreatment for $1 \mathrm{~h}$, Ca9-22 cells were treated with 0, 3, 6, 9, and $12 \mu \mathrm{M}$ of CPC for 6 and $12 \mathrm{~h}$. a Representative ROS profiles of flow cytometry for CPC treated Ca9-22 cells. The right side indicates the ROS positive region in each panel. b Quantification analysis of relative ROS intensity in Fig. 5a. Data, mean \pm SD $(n=3)$. For the same drug treatment of different concentrations, data marks (a to e) without overlapping by the same lower-case letter significantly differed (one-way ANOVA with Tukey HSD Post Hoc Test) 

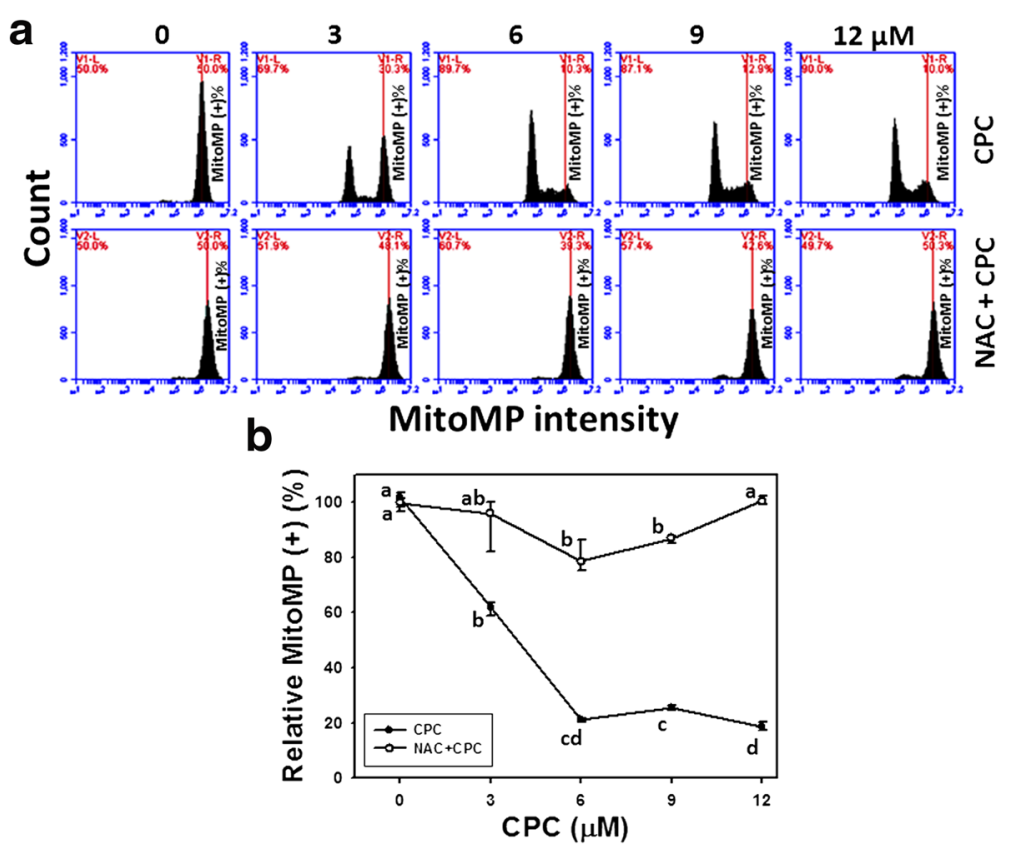

Fig. 6 Depolarization of mitochondrial membrane potential (MitoMP) of CPC-treated oral cancer Ca9-22 cells and the effect of NAC pretreatment. With or without $2 \mathrm{mM}$ NAC pretreatment for $1 \mathrm{~h}$, Ca9-22 cells were treated with 0, 3, 6, 9, and $12 \mu \mathrm{M}$ of CPC for $24 \mathrm{~h}$. a Representative MitoMP profiles of flow cytometry for CPC treated Ca9-22 cells. The right side indicates the MitoMP positive region in each panel. b Quantification analysis of relative MitoMP intensity in Fig. 6a. Data, mean \pm SD $(n=3)$. For the same drug treatment of different concentrations, data marks (a to d) without overlapping by the same lower-case letter significantly differed (one-way ANOVA with Tukey HSD Post Hoc Test)

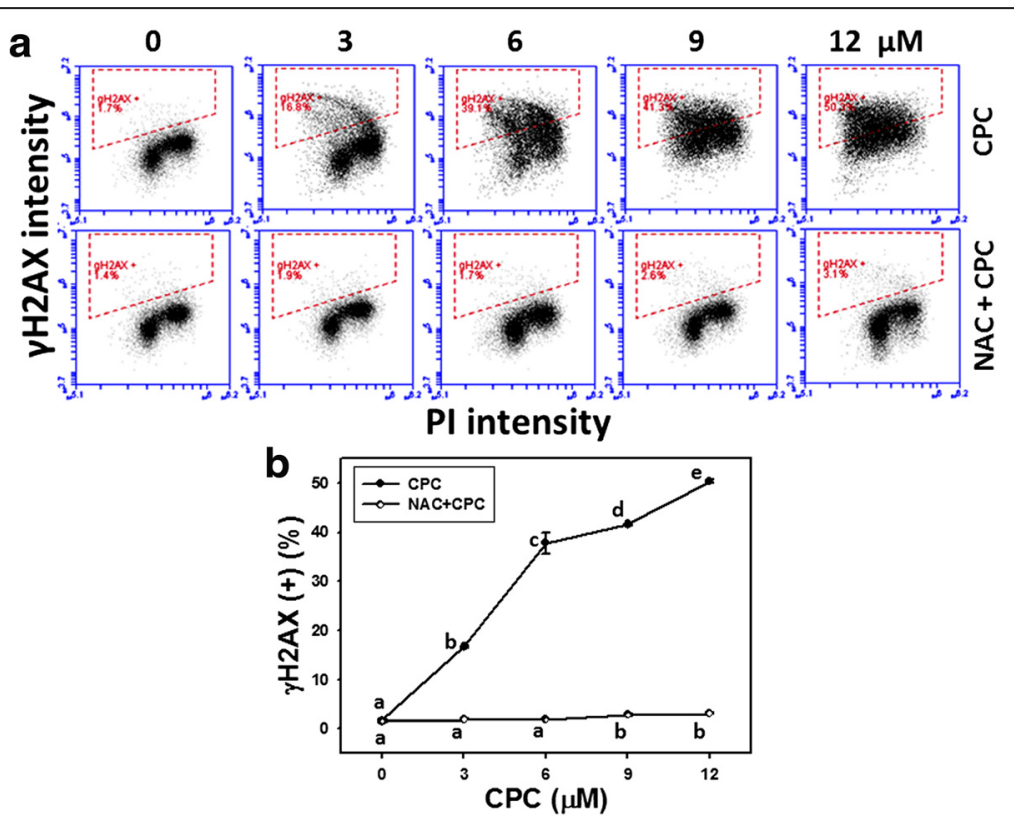

Fig. $7 \mathrm{YH} 2 \mathrm{AX}$-based DNA damage in CPC-treated oral cancer Ca9-22 cells and the effect of NAC pretreatment. With or without 2 mM NAC pretreatment for $1 \mathrm{~h}$, cells were treated with $0,3,6,9$, and $12 \mu \mathrm{M}$ of CPC for $24 \mathrm{~h}$. a Representative flow cytometry-based DSB profile for CPC-treated Ca9-22 cells. Dashed lines indicate the $\mathrm{YH} 2 \mathrm{AX}$ positive regions in each panel. $\mathbf{b}$ Quantification analysis of fold changes in $\mathrm{YH} 2 \mathrm{AX}-$ based DNA damage in CPC-treated Ca9-22 cells. Data, mean \pm SD $(n=3)$. For the same drug treatment of different concentrations, data marks (a to e) without overlapping by the same lower-case letter significantly differed (one-way ANOVA with Tukey HSD Post Hoc Test) 


\section{Discussion}

Cryptocarya-derived compounds were identified has having diverse biological functions including antiproliferation for several types of cancer. However, its effect on oral cancer cells has been less-well addressed. The current study examines the possible anti-oral cancer effect of C. concinna-derived CPC and explores drug response mechanism in detail.

\section{Selective killing of CPC}

Several anti-oral cancer drugs have harmful side effects for normal cells, thus limiting their clinical applications, and anticancer therapies ideally should have selective cell killing effects [21, 37]. In current study, we found that CPC were cytotoxic to two oral cancer cells but less harmful to oral normal cells (Fig. 1). Accordingly, CPC has the potential for selective killing to oral cancer cells.

\section{Comparison of drug sensitivity of CPC}

Cryptocaryone has recently been reported to inhibit proliferation of prostate cancer cells where its $\mathrm{IC}_{50}$ value is 1.6 to $3.4 \mu \mathrm{M} 48 \mathrm{~h}$ by SRB assay [19]. C. konishii-dervied cryptocaryone was found to inhibit proliferation of murine leukemia P-388 cells where its $\mathrm{IC}_{50}$ value is $0.04 \mu \mathrm{M}$ $48 \mathrm{~h}$ by MTT assay [17]. Cryptocaryone was also reported to be an active compound for antiproliferation in the $\mathrm{KB}$ cell lines with $\mathrm{IC}_{50}$ values $1.8 \mu \mathrm{M}$ at 3 days by MTT assay [39]. However, KB cells were recently found to be human cervical cancer HeLa cells rather than oral epidermal carcinoma [40]. Accordingly, the anti-oral cancer effects of cryptocaryone are still largely unknown. In the present study, we firstly found that CPC had an antiproliferative effect against oral cancer cells and the $\mathrm{IC}_{50}$ values of $\mathrm{CPC}$ in oral cancer Ca9-22 and CAL 27 cells at $24 \mathrm{~h}$ by MTS assay were 11.63 and $3.91 \mu \mathrm{g} / \mathrm{ml}$, respectively.

\section{The role of apoptosis in CPC studies}

The current study provides evidence for the apoptosis effect of CPC in oral cancer Ca9-22 cells, such as subG1 accumulation, annexin V/PI staining, and pancaspase analyses (Figs. 2, 3 and 4). Gene expression of apoptotic and anti-apoptotic proteins may be further validated by western blot or by PCR. For example, we found that apoptotic protein poly (ADP-ribose) polymerase (PARP $\gamma$ ) [41] of Ca9-22 cells and anti-apoptotic protein BCL2 [42] of CAL 27 cells was respectively up- and down-regulated after CPC treatments (data not shown). In future, work related to p53, p21, p27 and phospho p53 will be of more additional value to further find the detailed effect of CPC on apoptotic pathway. Similarly, cryptocaryone also reportedly induced apoptosis in human prostate cancer PC3 cells in terms of the subG1 accumulation, cleavage of caspase- 8 and 3 , death receptor DR5 accumulation on membranes, and up-regulation of Mcl-1 expression [19]. However, the role of oxidative stress of CPC-treated PC3 cells is not addressed. Instead, we had discussed the involvement of oxidative stress in CPC-treated oral cancer cells in next section.

The role of oxidative stress in dihydrochalcone studies $\mathrm{CPC}$ is a kind of dihydrochalcone that is shown to kill oral cancer cells (Fig. 1). Similarly, Muntingia calabura-derived dihydrochalcones $(2$ ', 4 ' -dihydroxy-3' -methoxydihydrochalcone and (-)-3' -methoxy-2', $4^{\prime}$, beta-trihydroxydihydrochalcone) have been reported to be cytotoxic to murine leukemia P-388 cells and human colon cancer HT-29 cells [43]. Corema album-derived dihydrochalcones $\left(2^{\prime}, 4^{\prime}\right.$-dihydroxydihydrochalcone and 2 '-methoxy-4' -hydroxydihydrochalcone) have been reported to be cytotoxic to colon cancer HT-29 cells [20] and their cell killing effects were reduced by NAC pretreatment [20], Consistently, we found that NAC pretreatment can inhibit CPC-induced ROS generation (Fig. 5) and mitochondrial depolarization (Fig. 6). Moreover, we also found that the CPC-induced subG1 accumulation, apoptosis (annexin $\mathrm{V}$ and caspase activities), and DNA damage were rescued by NAC pretreatment (Figs. 2, 3, 4 and 7). These findings suggest that oxidative stress may be involved in the cytotoxic activity of these dihydrochalcones. Moreover, oxidative stress may induce autophagy and apoptosis [44]. In future, it warrants for modulating autophagy and apoptosis by inhibitors such as 3-methyladenine/chloroquine [45] and Z-VAD-FMK [46] to investigate their individual contributions on $\mathrm{CPC}$ induced antiproliferation of oral cancer cells.

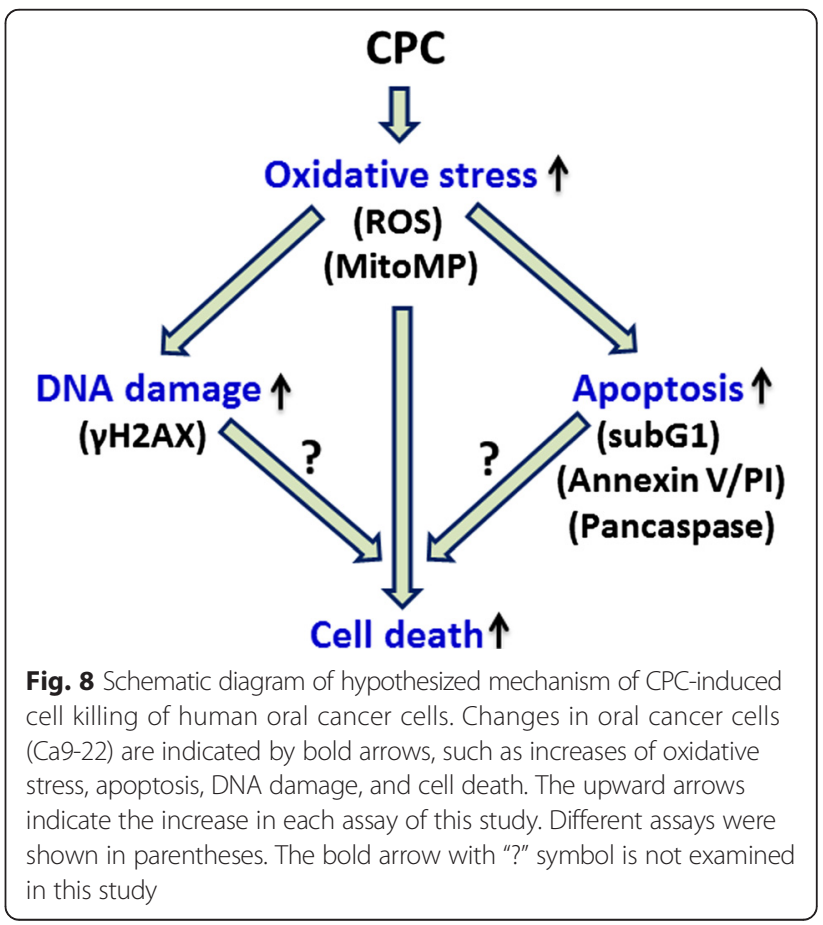


However, some dihydrochalcones may have different cell responses. For example, neohesperidin dihydrochalcone, a non-nutritive sweetening agent produced by hydrogenation of neohesperidin, displayed antioxidant properties to inhibit hypochlorous acid-induced DNA damage and cell death [47] and to inhibit carbon tetrachloride-induced oxidative damage both in vivo and in vitro [48]. Therefore, the functions of dihydrochalcones may have dual roles and may be dependent on its chemical properties, i.e., ROS generation or scavenging.

\section{Conclusion}

In conclusion, we demonstrate that $\mathrm{CPC}$ can inhibit cell proliferation and apoptosis of oral cancer cells but is less harmful to normal oral cells. This cell killing mechanism includes the ROS generation, mitochondrial depolarization, and DNA damage, which can be rescued by NAC pretreatment. Therefore, these results suggest that $\mathrm{CPC}$ has an anticancer potential for oxidative stress-mediated oral cancer therapy based on the cell line study (Fig. 8). In future, in vivo methods to explore the in vivo mechanism will provide concrete evidence of $\mathrm{CPC}$.

\section{Additional file}

Additional file 1: Figure S1. ${ }^{1} \mathrm{H}$ NMR and ${ }^{13} \mathrm{C}$ NMR spectrums of $C P C$. (DOCX $151 \mathrm{~kb}$ )

\section{Competing interests}

The authors declare that they have no competing interests.

\section{Authors' contributions}

$\mathrm{H}-\mathrm{SC}, \mathrm{J}-\mathrm{YT}$, and $\mathrm{H}-\mathrm{WC}$ participated in the manuscript writing. $\mathrm{M}-\mathrm{YH}$ and $\mathrm{H}-\mathrm{WC}$ participated in the study design. I-SC identified and collected the materials $C$. concinna. $\mathrm{H}-\mathrm{SC}$ prepared the CPC from C. concinna. $\mathrm{H}-\mathrm{WH}$ instructed Y-AC to perform the flow cytometer and analyzed data. C-YW instructed $Y$-AC to perform the survival assay and analyzed data. J-YT, C-YY, and H-RW performed statistical analysis. M-YH and H-WC coordinated and oversaw the study. All authors read and approved the final manuscript.

\section{Acknowledgements}

This work was supported by funds of the Ministry of Science and Technology (MOST 104-2320-B-037-013-MY3, MOST 103-2314-B-037-010-MY3, MOST 103-2320B-037-008, and NSC 101-2320-B-037-049), the Kaohsiung Medical University "Aim for the Top Universities Grant, grant No. KMU-TP103A33, KMU-TP103H01, KMU-TP103H05, and KMU-TP104PR02", the National Sun Yat-sen University-KMU Joint Research Project (\#NSYSU-KMU 105-P002), the Kaohsiung Municipal Ta-Tung Hospital (kmtth-104-003), the Kaohsiung Medical University Hospital (KMUH103-3M39), the Health and welfare surcharge of tobacco products, the Ministry of Health and Welfare, Taiwan, Republic of China (MOHW104-TDU-B212-124-003 and MOHW105-TDU-B-212-134005), and ChiMei-KMU Joint Project (104CM-KMU-02). We thank the Center for Research Resources and Development of Kaohsiung Medical University for providing the service of Nuclear Magnetic Resonance. We also thank for the help in English editing by Dr. Hans-Uwe Dahms.

\section{Author details}

'Graduate Institute of Natural Products, College of Pharmacy, Kaohsiung Medical University, Kaohsiung, Taiwan. ${ }^{2}$ School of Pharmacy, College of Pharmacy, Kaohsiung Medical University, Kaohsiung, Taiwan. ${ }^{3}$ Department of Radiation Oncology, Faculty of Medicine, College of Medicine, Kaohsiung Medical University, Kaohsiung, Taiwan. ${ }^{4}$ Department of Radiation Oncology,
Kaohsiung Medical University Hospital, Kaohsiung, Taiwan. ${ }^{5}$ Department of Radiation Oncology, Kaohsiung Municipal Ta-Tung Hospital, Kaohsiung, Taiwan. ${ }^{6}$ Department of Oral and Maxillofacial Surgery Chi-Mei Medical Center, Tainan, Taiwan. ${ }^{7}$ School of Dentistry, Taipei Medical University, Taipei, Taiwan. ${ }^{8}$ Institute of Biomedical Science, National Sun Yat-Sen University, Kaohsiung, Taiwan. ${ }^{9}$ Department of Biological Sciences, National Sun Yat-Sen University, Kaohsiung, Taiwan. ${ }^{10}$ Department of Biomedical Science and Environmental Biology, Kaohsiung Medical University, Kaohsiung, Taiwan. ${ }^{11}$ Institute of Medical Science and Technology, National Sun Yat-Sen University, Kaohsiung, Taiwan. ${ }^{12}$ Cancer Center, Kaohsiung Medical University Hospital, Kaohsiung Medical University, Kaohsiung, Taiwan. ${ }^{13}$ Center for Reseach Resources and Development of Kaohsiung Medical University, Kaohsiung, Taiwan.

Received: 12 August 2015 Accepted: 2 March 2016

Published online: 08 March 2016

\section{References}

1. Warnakulasuriya S. Global epidemiology of oral and oropharyngeal cancer. Oral Oncol. 2009;45(4-5):309-16.

2. Petersen PE. Oral cancer prevention and control-the approach of the World Health Organization. Oral Oncol. 2009;45(4-5):454-60.

3. Myoung H, Hong SP, Yun PY, Lee JH, Kim MJ. Anti-cancer effect of genistein in oral squamous cell carcinoma with respect to angiogenesis and in vitro invasion. Cancer Sci. 2003;94(2):215-20.

4. Yen $\mathrm{CY}$, Chen $\mathrm{CH}$, Chang $\mathrm{CH}$, Tseng HF, Liu SY, Chuang LY, Wen CH, Chang HW. Matrix metalloproteinases (MMP) 1 and MMP10 but not MMP12 are potential oral cancer markers. Biomarkers. 2009;14(4):244-9.

5. Yen $\mathrm{CY}$, Huang $\mathrm{CY}$, Hou MF, Yang $\mathrm{YH}$, Chang $\mathrm{CH}$, Huang HW, Chen $\mathrm{CH}$, Chang HW. Evaluating the performance of fibronectin 1 (FN1), integrin alpha4beta1 (ITGA4), syndecan-2 (SDC2), and glycoprotein CD44 as the potential biomarkers of oral squamous cell carcinoma (OSCC). Biomarkers. 2013;18(1):63-72.

6. Davies-Coleman MT, Rivett DEA. Naturally occurring 6-substituted 5,6-dihydroa-pyrones. Prog Chem Org Nat Prod. 1989;55:1-35.

7. Ong CY, Ling SK, Ali RM, Chee CF, Samah ZA, Ho AS, Teo SH, Lee HB. Systematic analysis of in vitro photo-cytotoxic activity in extracts from terrestrial plants in Peninsula Malaysia for photodynamic therapy. J Photochem Photobiol B. 2009;96(3):216-22.

8. Huang HW, Chung YA, Chang HS, Tang JY, Chen IS, Chang HW. Antiproliferative effects of methanolic extracts of Cryptocarya concinna Hance roots on oral cancer Ca9-22 and CAL 27 cell lines involving apoptosis, ROS induction, and mitochondrial depolarization. ScientificWorldJournal. 2014;2014:180462.

9. Dumontet V, Van Hung N, Adeline MT, Riche C, Chiaroni A, Sevenet T, Gueritte F. Cytotoxic flavonoids and alpha-pyrones from Cryptocarya obovata. J Nat Prod. 2004;67(5):858-62.

10. Allard PM, Dau ET, Eydoux C, Guillemot JC, Dumontet V, Poullain C, Canard B, Gueritte F, Litaudon M. Alkylated flavanones from the bark of Cryptocarya chartacea as dengue virus NS5 polymerase inhibitors. J Nat Prod. 2011; 74(11):2446-53.

11. Wu TS, Sun CR, Lee KH. Cytotoxic and anti-HIV phenanthroindolizidine alkaloids from Cryptocarya chinensis. Nat Prod Commun. 2012;7(6):725-7.

12. Chou TH, Chen JJ, Peng CF, Cheng MJ, Chen IS. New flavanones from the leaves of Cryptocarya chinensis and their antituberculosis activity. Chem Biodivers. 2011;8(11):2015-24.

13. Nasrullah AA, Zahari A, Mohamad J, Awang K. Antiplasmodial alkaloids from the bark of Cryptocarya nigra (Lauraceae). Molecules. 2013;18(7):8009-17.

14. Davis RA, Demirkiran O, Sykes ML, Avery VM, Suraweera L, Fechner GA, Quinn RJ. 7',8'-Dihydroobolactone, a typanocidal alpha-pyrone from the rainforest tree Cryptocarya obovata. Bioorg Med Chem Lett. 2010;20(14):4057-9.

15. Feng R, Guo ZK, Yan CM, Li EG, Tan RX, Ge HM. Anti-inflammatory flavonoids from Cryptocarya chingii. Phytochemistry. 2012;76:98-105.

16. Usman H, Hakim EH, Harlim T, Jalaluddin MN, Syah YM, Achmad SA, Takayama H. Cytotoxic chalcones and flavanones from the tree bark of Cryptocarya costata. Z Naturforsch C. 2006;61(3-4):184-8.

17. Kurniadewi F, Juliawaty LD, Syah YM, Achmad SA, Hakim EH, Koyama K, Kinoshita K, Takahashi K. Phenolic compounds from Cryptocarya konishii: their cytotoxic and tyrosine kinase inhibitory properties. J Nat Med. 2010;64(2):121-5.

18. Liao JC. Lauraceae in Flora of Taiwan, 2nd ed. Editorial Committee of the Flora of Taiwan; Taipei, Taiwan. 1996, 2:448-451. 
19. Chen YC, Kung FL, Tsai IL, Chou TH, Chen IS, Guh JH. Cryptocaryone, a natura dihydrochalcone, induces apoptosis in human androgen independent prostate cancer cells by death receptor clustering in lipid raft and nonraft compartments. J Urol. 2010;183(6):2409-18.

20. Leon-Gonzalez AJ, Lopez-Lazaro M, Espartero JL, Martin-Cordero C. Cytotoxic activity of dihydrochalcones isolated from Corema album leaves against HT-29 colon cancer cells. Nat Prod Commun. 2013;8(9):1255-6.

21. Chiu CC, Haung JW, Chang FR, Huang KJ, Huang HM, Huang HW, Chou CK, Wu YC, Chang HW. Golden berry-derived 4beta-hydroxywithanolide E for selectively killing oral cancer cells by generating ROS, DNA damage, and apoptotic pathways. PLoS One. 2013;8(5):e64739.

22. Jiang L, Ji N, Zhou Y, Li J, Liu X, Wang Z, Chen Q, Zeng X. CAL 27 is an oral adenosquamous carcinoma cell line. Oral Oncol. 2009;45(11):e204-207.

23. Chen BH, Chang HW, Huang HM, Chong IW, Chen JS, Chen CY, Wang HM. (-)-Anonaine induces DNA damage and inhibits growth and migration of human lung carcinoma h1299 cells. J Agric Food Chem. 2011;59(6):2284-90.

24. Chiu CC, Liu PL, Huang K, Wang HM, Chang KF, Chou CK, Chang FR, Chong IW, Fang K, Chen JS et al. Goniothalamin inhibits growth of human lung cancer cells through DNA damage, apoptosis, and reduced migration ability. J Agric Food Chem. 2011;59(8):4288-93.

25. Kaufmann SH, Lee SH, Meng XW, Loegering DA, Kottke TJ, Henzing AJ, Ruchaud S, Samejima K, Earnshaw WC. Apoptosis-associated caspase activation assays. Methods. 2008;44(3):262-72.

26. Yeh CC, Tseng CN, Yang Jl, Huang HW, Fang Y, Tang JY, Chang FR, Chang HW. Antiproliferation and induction of apoptosis in Ca9-22 oral cancer cells by ethanolic extract of Gracilaria tenuistipitata. Molecules. 2012;17(9):10916-27.

27. Yeh CC, Yang Jl, Lee JC, Tseng CN, Chan YC, Hseu YC, Tang JY, Chuang LY, Huang HW, Chang FR. Anti-proliferative effect of methanolic extract of Gracilaria tenuistipitata on oral cancer cells involves apoptosis, DNA damage, and oxidative stress. BMC Complement Altern Med. 2012;12(1):142.

28. Yen CY, Chiu CC, Haung RW, Yeh CC, Huang KJ, Chang KF, Hseu YC, Chang FR, Chang HW, Wu YC. Antiproliferative effects of goniothalamin on Ca9-22 oral cancer cells through apoptosis, DNA damage and ROS induction. Mutat Res. 2012;747(2):253-8

29. Yu FS, Yang JS, Yu CS, Lu CC, Chiang JH, Lin CW, Chung JG. Safrole induces apoptosis in human oral cancer HSC-3 cells. J Dent Res. 2011;90(2):168-74.

30. Yen CY, Hou MF, Yang ZW, Tang JY, Li KT, Huang HW, Huang YH, Lee SY, Fu TF, Hsieh $\mathrm{CY}$ et al. Concentration effects of grape seed extracts in anti-oral cancer cells involving differential apoptosis, oxidative stress, and DNA damage. BMC Complement Altern Med. 2015;15(1):94.

31. Chan WH, Shiao NH, Lu PZ. CdSe quantum dots induce apoptosis in human neuroblastoma cells via mitochondrial-dependent pathways and inhibition of survival signals. Toxicol Lett. 2006;167(3):191-200.

32. Shieh JM, Shen CJ, Chang WC, Cheng HC, Chan YY, Huang WC, Chang WC, Chen BK. An increase in reactive oxygen species by deregulation of ARNT enhances chemotherapeutic drug-induced cancer cell death. PLoS One. 2014;9(6):e99242.

33. Lee WC, Li LC, Chen JB, Chang HW. Indoxyl sulfate-induced oxidative stress, mitochondrial dysfunction, and impaired biogenesis are partly protected by Vitamin C and N-acetylcysteine. ScientificWorldJournal. 2015;2015:620826.

34. Lin MH, Hsieh WF, Chiang WF, Hong WZ, Hsu YR, Cheng YC, Chen TC, Hsu KC, Lin PY, Liu SY. Autophagy induction by the 30-100 kDa fraction of areca nut in both normal and malignant cells through reactive oxygen species. Oral Oncol. 2010;46(11):822-8.

35. Yen CY, Lin MH, Liu SY, Chiang WF, Hsieh WF, Cheng YC, Hsu KC, Liu YC. Arecoline-mediated inhibition of AMP-activated protein kinase through reactive oxygen species is required for apoptosis induction. Oral Oncol. 2011:47(5):345-51.

36. Han MH, Park C, Jin CY, Kim GY, Chang YC, Moon SK, Kim WJ, Choi YH. Apoptosis induction of human bladder cancer cells by sanguinarine through reactive oxygen species-mediated up-regulation of early growth response gene-1. PLoS One. 2013;8(5):e63425.

37. Raj L, Ide T, Gurkar AU, Foley M, Schenone M, Li X, Tolliday NJ, Golub TR, Carr SA, Shamji AF et al. Selective killing of cancer cells by a small molecule targeting the stress response to ROS. Nature. 2011;475(7355):231-4.

38. Ding H, Han C, Guo D, Chin YW, Ding Y, Kinghorn AD, D'Ambrosio SM. Selective induction of apoptosis of human oral cancer cell lines by avocado extracts via a ROS-mediated mechanism. Nutr Cancer. 2009;61(3):348-56.
39. Dumontet V, Gaspard C, Hung NV, Fahy J, Tchertanov L, Se'venet T, Gue'ritte F. New cytotoxic flavonoids from Cryptocarya infectoria. Tetrahedron. 2001;57: 6189-96.

40. Masters J. False cell lines. Carcinogenesis. 2002;23(2):371.

41. Yen YH, Farooqi AA, Li KT, Butt G, Tang JY, Wu CY, Cheng YB, Hou MF, Chang HW. Methanolic extracts of Solieria robusta inhibits proliferation of oral cancer Ca9-22 cells via apoptosis and oxidative stress. Molecules. 2014; 19(11):18721-32.

42. Belka C, Budach W. Anti-apoptotic Bcl-2 proteins: structure, function and relevance for radiation biology. Int J Radiat Biol. 2002;78(8):643-58.

43. Chen JJ, Lee HH, Duh CY, Chen IS. Cytotoxic chalcones and flavonoids from the leaves of Muntingia calabura. Planta Med. 2005;71(10):970-3.

44. Faroogi AA, Fayyaz S, Hou MF, Li KT, Tang JY, Chang HW. Reactive oxygen species and autophagy modulation in non-marine drugs and marine drugs. Mar Drugs. 2014;12(11):5408-24.

45. Palmeira dos Santos C, Pereira GJ, Barbosa CM, Jurkiewicz A, Smaili SS, Bincoletto C. Comparative study of autophagy inhibition by 3MA and CQ on Cytarabine induced death of leukaemia cells. J Cancer Res Clin Oncol. 2014;140(6):909-20.

46. Callus BA, Vaux DL. Caspase inhibitors: viral, cellular and chemical. Cell Death Differ. 2007;14(1):73-8

47. Choi JM, Yoon BS, Lee SK, Hwang JK, Ryang R. Antioxidant properties of neohesperidin dihydrochalcone: inhibition of hypochlorous acid-induced DNA strand breakage, protein degradation, and cell death. Biol Pharm Bull. 2007;30(2):324-30

48. Hu L, Li L, Xu D, Xia X, Pi R, Xu D, Wang W, Du H, Song E, Song Y Protective effects of neohesperidin dihydrochalcone against carbon tetrachloride-induced oxidative damage in vivo and in vitro. Chem Biol Interact. 2014;213:51-9.

\section{Submit your next manuscript to BioMed Central and we will help you at every step:}

- We accept pre-submission inquiries

- Our selector tool helps you to find the most relevant journal

- We provide round the clock customer support

- Convenient online submission

- Thorough peer review

- Inclusion in PubMed and all major indexing services

- Maximum visibility for your research

Submit your manuscript at www.biomedcentral.com/submit
Biomed Central 